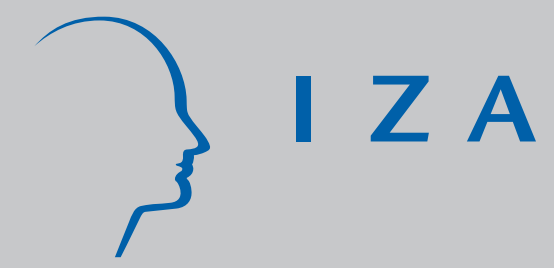

IZA DP No. 1050

The Impact of Family-Friendly Policies in Denmark and Sweden on Mothers' Career Interruptions Due to Childbirth

Elina Pylkkänen

Nina Smith

March 2004 


\title{
The Impact of Family-Friendly Policies in Denmark and Sweden on Mothers' Career Interruptions Due to Childbirth
}

\author{
Elina Pylkkänen \\ University of Göteborg \\ and Swedish Ministry of Finance \\ Nina Smith \\ Aarhus School of Business, CIM, \\ DIW Berlin and IZA Bonn

\section{Discussion Paper No. 1050 \\ March 2004}

\author{
IZA \\ P.O. Box 7240 \\ 53072 Bonn \\ Germany \\ Phone: +49-228-3894-0 \\ Fax: +49-228-3894-180 \\ Email: iza@iza.org
}

\begin{abstract}
Any opinions expressed here are those of the author(s) and not those of the institute. Research disseminated by IZA may include views on policy, but the institute itself takes no institutional policy positions.
\end{abstract}

The Institute for the Study of Labor (IZA) in Bonn is a local and virtual international research center and a place of communication between science, politics and business. IZA is an independent nonprofit company supported by Deutsche Post World Net. The center is associated with the University of Bonn and offers a stimulating research environment through its research networks, research support, and visitors and doctoral programs. IZA engages in (i) original and internationally competitive research in all fields of labor economics, (ii) development of policy concepts, and (iii) dissemination of research results and concepts to the interested public.

IZA Discussion Papers often represent preliminary work and are circulated to encourage discussion. Citation of such a paper should account for its provisional character. A revised version may be available on the IZA website (www.iza.org) or directly from the author. 


\section{ABSTRACT \\ The Impact of Family-Friendly Policies in Denmark and Sweden on Mothers' Career Interruptions Due to Childbirth*}

We analyze the impact of family-friendly policies on women's career breaks due to childbirth in Denmark and Sweden. In both countries, the labour force attachment of mothers is high, and more than $90 \%$ of the women return to work after childbirth. Sweden and Denmark are culturally similar and share the same type of welfare state ideology, but differ remarkably in pursued family policies. The impact of family policy variables on the probability of returning to the labour market is estimated using a duration model approach. Our results show that economic incentives and leave periods of the fathers affect the behaviour of mothers in both countries. However, family policy instruments are found to have a much larger impact on Swedish mothers' behaviour compared to Danish women. We explain this finding by the fact that family-friendly policies in Sweden have focused much more on flexible leave schemes and on the shared responsibilities of the parents than in Denmark.

JEL Classification: J1, J22

Keywords: family-friendly policy, maternal leave, paternal leave, childcare

Corresponding author:

Nina Smith

Aarhus School of Business

Prismet

Silkeborgvej 2

8000 Aarhus C

Denmark

Email: nina@asb.dk

\footnotetext{
* Thanks to Astrid Würtz, Grethe Leth Pedersen and Allan Schmidt Klausen who have done part of the computational work. We thank Willem Adema (OECD), Lennart Flood, Peter Jensen, participants at the EALE 2003 conference in Seville and members of the Long Time Survey Team at the Ministry of Finance, Sweden, for valuable comments and creative and critical discussions. We thank the Ministry of Finance, Sweden, Göteborgs Universitets Jubileumsfonden, the Danish Social Research Council (FREJA) and OECD for financial support.
} 
Introduction

Over the past thirty years, employment rates of mothers with young children have increased in almost all countries. However, this trend has been accompanied by a large decrease in fertility in most countries, see OECD (2001). In contrast, the Nordic countries have not experienced such a strong trade-off between mothers' employment and fertility. Both female employment and fertility rates have been high in an international perspective. Female employment rates for young women are close to $80 \%$ and fertility rates are only slightly lower than 2 . Studies on female labour supply show that contrary to most other countries where young children have a large negative impact on mothers' labour supply this effect is much smaller or non-existing in the Nordic countries (see Smith et al., 2003).

The family policies in the Nordic countries have a long tradition in offering facilities and subsidies to encourage mothers to combine family and work, see for instance Esping-Andersen (2002). Many international comparative studies show that women appear to increase their attachment to the labour force when given the opportunity to take paid leave (see for example Ruhm and Teague, 1997; Joesh, 1995; Waldfogel et al., 1999). Thus, the positive effects to the labour market tend to outweigh the costs of conducting such parental leave and benefit policies and therefore they legitimize these family-friendly polices Joesh, 1995; Gustafsson et al., 1996; Rönsen and Sundström, 1996, Joshi et al., 1996). Ruhm's (1998) comprehensive comparative study on European countries, for example, finds that parental leave legislation raises the female employment-to-population rate by 3-4\%, and even more for women of childbearing age. There may also be negative effects of very generous family-friendly schemes if these schemes are mainly picked up by the mothers and not the fathers (see Nielsen et al., 2002; Datta Gupta and Smith, 2002). The schemes may reduce the human capital of women compared to men, and they may give rise to statistical discrimination effects, reduce women's wage growth and increase the gender wage gap. However, in this paper we do not focus on these potential negative effects of family-friendly policies.

Instead the aim is to study the duration of career interruptions contingent to childbirth of Danish and Swedish women. Which factors affect a mother's decision to return to work after childbirth? How important are the benefit compensation rate and the prices and availability of publicly provided childcare? How do the availability and eligibility rules concerning fathers' leave affect the length of the career break of the mothers? Are the parents in practice able (and willing) to substitute their time allocated to the market and the home or do the families for some reasons 
seem to be 'locked in corner solutions' where economic incentives or availability of parental schemes open for both parents do not affect the labour market behaviour of the families. These questions are important because they may give an answer to how flexible the social system and the labour market are with respect to allowing the parents effectively to choose how to allocate parental time after a childbirth. Since family-friendly policies aim at facilitating the balance between family responsibilities and the demands of the labour market, or expressed alternatively, at increasing women's participation in the labour market without reducing fertility rates, it is very important to study how different family policies affect families' behaviour.

Our analysis takes advantage of the availability of comparable longitudinal data. These data allow us to estimate parallel models across the countries in order to determine to which extent the family-leave policies affect women's retention. The study examines Danish and Swedish mothers who participate in the labour market and interrupt their careers due to childbirth during the 1990s. Here we also make use of fathers' characteristics and their uptake of parental leave. It is interesting to compare these two culturally similar countries which share the same pattern of employment of women overall and of women with young children in particular, but differ remarkably in their family policies. Sweden has implemented fairly long maternal and parental leave schemes compared to Denmark, where on the other hand the coverage of publicly provided and subsidized childcare for children aged less than 3 has been considerably higher than in Sweden (Ellingsäter, 1998). In Sweden, the political agenda has focused much more on equal opportunities issues and how to design policies to promote equal opportunities, while the Danish political discourse has been much more based on liberal attitudes towards families' decisions concerning the take-up of parental leave by fathers and mothers and the labour market response to these decisions.

The raw data and the empirical estimations clearly show that women have a very high probability of returning to employment when the parental leave has expired (well over $90 \%$ do return). The rules of parental leave schemes as well as other parts of the family policy regimes affect the mothers' decision on job retention. The same seems to apply to men. When given explicitly the possibility of taking parental leave, the majority of fathers (about $70 \%$ of fathers in Sweden and almost $50 \%$ of fathers in Denmark) make use of it. However, very few of the Danish fathers take more than two weeks of parental leave just after the childbirth. The much more flexible Swedish system and the more focus on equalization of parents' use of parental scheme compared to Denmark may have implied that Swedish parents to a larger extent than Danish parents are 
actually able or willing to adapt policy changes. For Denmark, we find that family policies do not affect mothers' behaviour much, either because the Danish parents are too far away from economic conditions where they were actually able or willing to substitute parents' time, or because the labour market does not allow this substitution in practice.

The structure of the paper is the following. The next section shortly describes the family policies in Denmark and Sweden. Section 3 summarizes some of the recent international studies about the impact of family policies on mother's employment. In Section 4, the econometric model is presented. The description of data is presented in Section 5. Section 6 analyzes the results from the estimations and policy simulations, and Section 7 concludes.

\section{Earlier Studies of Labour Supply Effects of Family Policy Schemes}

According to many comparative studies, the impact of family policies on mothers' (or fathers') return to work can be quite substantial. A large literature provides information on how different policies result in different labour force attachments of women. Waldfogel et al. (1999) compare mothers in the US, Britain and Japan and find that young children have a very strong negative effect on women's employment. However, they find strong evidence that family leave coverage increases the likelihood that a woman will return to employment after childbirth in all three countries investigated. They conclude that the recent expansions in family leave coverage in these countries are likely to lead to increased employment of women after childbirth and in some cases even boost job retention. Ruhm (1998) investigates the economic consequences of paid parental leave in nine European countries and finds that a right to paid leave raises the employment rate of women. Even short durations of guaranteed work absence have a substantial effect on female employment. These results are confirmed for Germany in a study by Ondrich et al. (1999).

A longer entitlement period, such as the Swedish one, tends to lengthen the time out of employment shortly after childbirth, but in the long run a longer leave period enables more parents (mothers) to join and stay in the labour force and therefore it results in higher overall reentry rates. Rönsen and Sundström (1996) study the impact of family policies on the return to work by comparing the post-birth employment activity of Norwegian and Swedish women. They analyze rates of re-entry into paid work after the first birth for mothers in 1968-1988. The most important findings are that the right to paid maternity leave with job-protection speeds up the return to employment and that women who have this right are much more likely to resume employment. However, part of this effect may be due to the fact that the women eligible for 
leave schemes are women with a more permanent attachment to the labour market and the strongest preferences for market work. Extensions in leave schemes and the so-called Swedish "speed-premium" on the next birth have, though, delayed the return to work.

Gustafsson et al. (1996) analyze labour force transitions around childbirth and the extent to which lower labour force participation rates of mothers are explained by different family policies. They compare German, Swedish and British women and find that different welfare policy regimes produce different outcomes in labour force participation among mothers. These countries represent the three main types of different welfare states. The difference in total labour force participation of women is a result of fewer mothers entering the labour force and entering later after births in Germany and Great Britain than in Sweden. Although there is no such difference before the birth of the first child, the difference is more pronounced for second and third births.

In the study by Gustafsson et al. (1996), it is found that women's own human capital is important both in Germany and Great Britain, whereas in Sweden also less educated women have entered the labour force by the time the child is two years old. The same result is found in Klerman and Leibowitz (1990) and Joesh (1994). Family income has been reported to have either a negative or no relationship with the timing of post-birth employment (Wenk and Garrett, 1992). Results are more mixed for most other factors, such as education level, age at birth, marital status and race (Wenk and Garrett, 1992). For Sweden, Rönsen and Sundström (1996) found that more educated women have shorter career breaks contingent to childbirth compared to less educated women.

There is less recent empirical research on the effects of childcare programs on parents' (mothers') work choices and families' decisions about how to provide care for their children. Lack of formal and affordable good quality care may constrain mothers to take paid employment, see OECD (2001). The limited empirical evidence within this area is probably due to lack of data on availability, prices and type of childcare. A recent comprehensive study based on British data is found in Paull et al. (2002) and OECD (2002). 
Although the Danish and Swedish family policies are much more developed compared to most other countries, there are large differences in the rules concerning parental leave programs as well as the coverage and price structure of childcare. ${ }^{1}$

\subsection{Parental Leave Schemes}

On the whole, the Swedish parental leave schemes are highly flexible and fairly generous compared to the Danish schemes. The principal idea in the Swedish system is that parenthood is considered to be a shared responsibility between the mother and the father. Fathers are therefore particularly encouraged to take leave, which has resulted in a very recent policy reform providing a minimum of two months of ring-fenced leave for either parent that is not transferable to the other parent (the two months for the father are often denoted the "father quota"). The leave period of in total 360 days may be split in a number of shorter spells or part-time work in a very flexible way, see description in the Appendix. Compared to Sweden, the leave schemes in Denmark have been rather inflexible in the sense that until recently it has not really been possible to split the leave period in several periods. 14 weeks after childbirth are reserved for the mother and the next 10 weeks of parental leave may be taken up by either of the parents. During the period 1994-2001, the parents could add an additional childcare scheme after 24 weeks with a lower compensation rate, see description in the Appendix. Thus the period of parental leave which can be taken by either parent is much shorter in Denmark than in Sweden, and a ringfenced leave for the father has only existed for a short period from 1999 to 2002, except for two weeks in connection with childbirth. In both countries, the length of the leave period has been extended over the years.

Figure 1 shows the duration in weeks of maternal and paternal leave periods in Denmark and Sweden for two national samples of individuals who became parents during the period 1993-96 (Denmark) and 1993-98 (Sweden). According to the figure, Danish women tend to a much larger extent than Swedish women to return to work after a leave period of 25-28 weeks (6-7 months) while the much more smooth Swedish distribution indicates a larger variation of the length of leave periods for Swedish women, with a peak at 9-10 months. This may reflect the much more flexible Swedish leave schemes which allow mothers to return to work before the leave period

\footnotetext{
${ }^{1}$ In this paper, we do not analyze the impact of the taxation scheme, i.e. whether joint, split or separate taxation on the labour supply of the fathers and mothers. In both countries, the tax schemes are based on the separate taxation principle, which is neutral with respect to the relative incentives to work for the spouses, see Smith et al. (2003).
} 
expires, without loosing the right to use the rest of the leave period at a later point in time. The fathers' leave periods also show large differences between Sweden and Denmark. Apparently, there are two types of Danish men, those who take up 2 weeks and those who do not take up any weeks on paternal leave. Then there is a very small group of Danish men who take up more than 2 weeks. The distribution of Swedish men is much more smooth, and a much larger proportion than Danish men has fairly long paternal leave periods, i.e. more than 2 weeks.

Figure 1. Duration of parental leave of mothers (the upper panels) and fathers (the lower panels).

\section{SWEDEN}
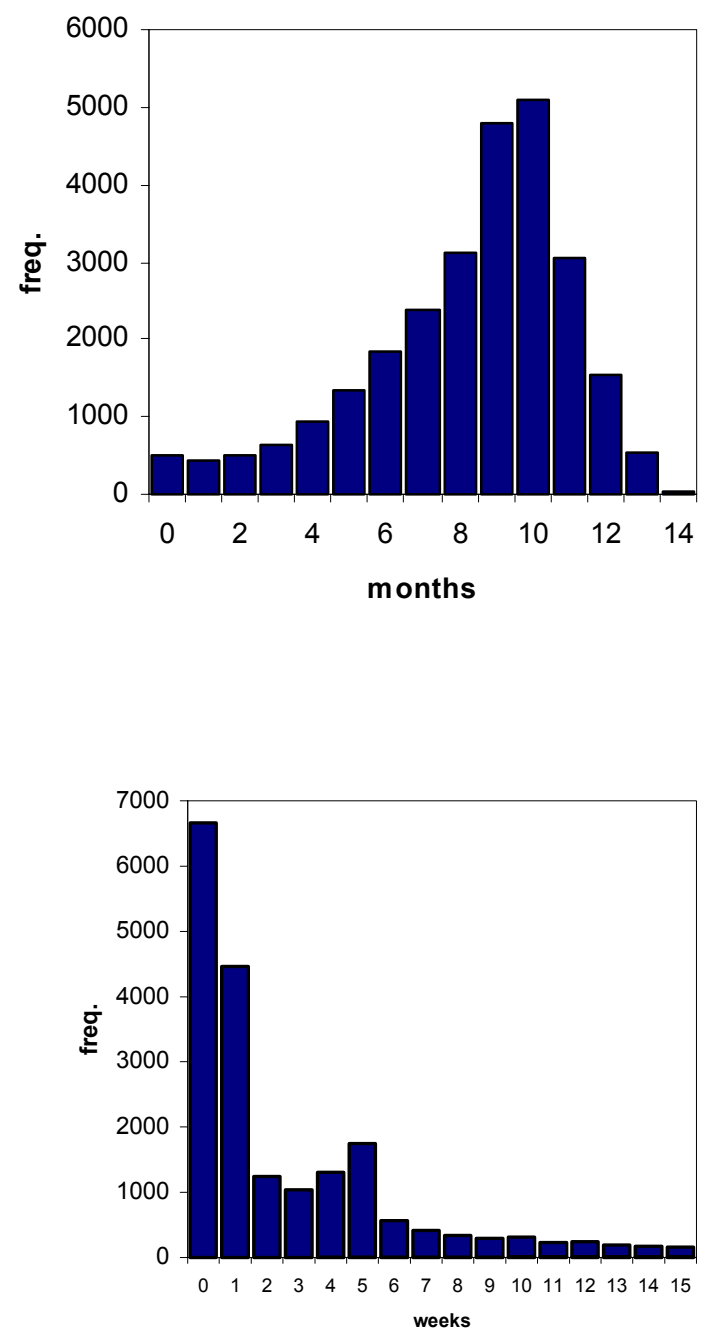

DENMARK
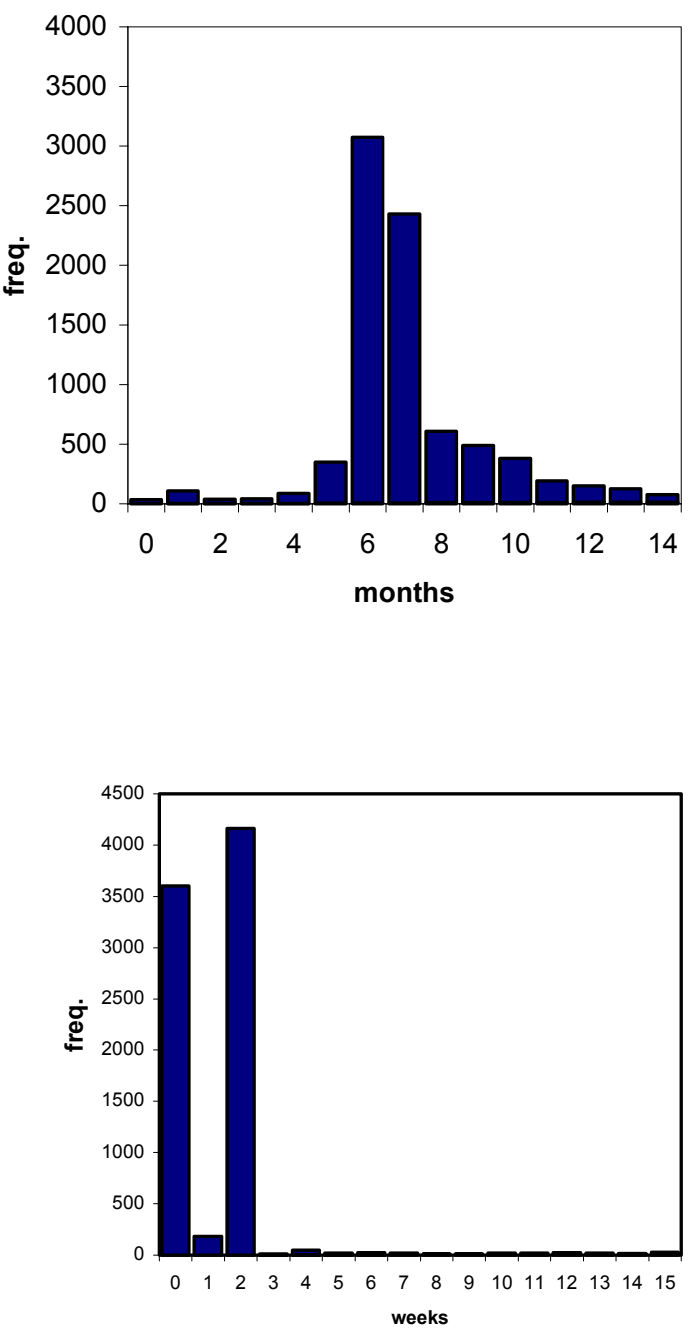

In Sweden, the compensation rate has been slightly reduced during the 1990s, whereas in Denmark the tendency is mixed; for some schemes the compensation has increased, for others reduced. Most Swedish parents, including the fathers, receive a compensation rate of $80-90 \%$ of former wage income. In Denmark, the compensation rate during the first 24 weeks varies, 
according to sector. If employed in the public sector, there is a $100 \%$ compensation while the compensation rate in most of the private sector equals the level of unemployment benefits. Since the majority of mothers are employed in the public sector and get full compensation, see Nielsen et al. (2002), while more than $80 \%$ of the fathers are employed in the private sector and receive a compensation often less than half of former wage level, this means strong incentives for mothers to take up the majority of the leave period. In Figure 2, we show the average compensation rate during the leave period, i.e. a weighted average of the compensation rate for men and women in the two countries.

Figure 2. Compensation rates during the leave period for women (upper panels) and men (lower panels). Sweden $(\mathrm{n}=21018)$ and Denmark (mothers $=8117$, fathers $=6549)$.
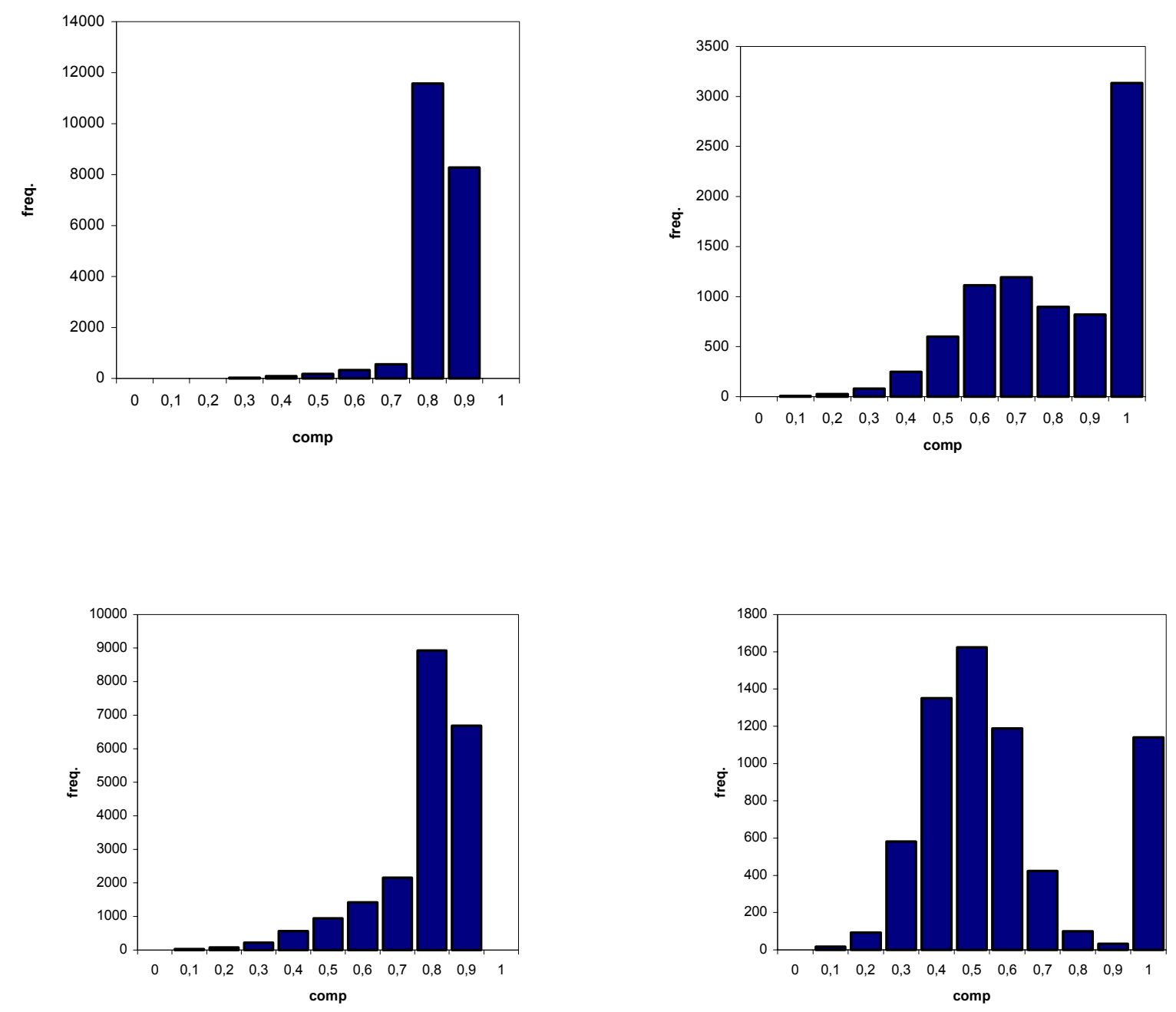
Most Swedish women receive a compensation rate around 80-90\%. For Danish women, the variation is much larger, with about half the women receiving full pay (publicly employed) while the rest have much lower compensation rates than in Sweden. The same pattern is observed for fathers in the two countries, but in both countries the fathers tend to have lower compensation rates than mothers.

\subsection{Childcare}

A major aspect of the effect of children on the earning capacity of parents is the access to as well as the quality and prices of childcare facilities. If it was easy and relatively cheap to get childcare, the earnings capacity of the parents (mothers) might well be less "damaged" than in countries where childcare facilities are scarce or expensive. Furthermore, if the quality or stability of the childcare arrangements is low, it may induce higher absenteeism from work and lower the productivity of the parents (mothers), compared to countries with high coverage along with high quality and stable childcare. In Sweden and Denmark, the coverage of publicly provided childcare for children below 3 years has increased considerably during the last decades (see OECD, 2001). Despite the large expansion, there is a constant shortage of childcare places in both Sweden and Denmark. One major reason is that public childcare is highly subsidized, i.e. the price is much lower than the actual price of producing these services. The quality is fairly high in an international setting when measured by the staffing and economic resources spent on public childcare (see Rostgaard and Fridberg, 1998; Waldfogel, 1998, for international surveys of childcare systems). As seen from Figure 3, which shows the distribution of prices of publicly provided childcare in the local municipalities in Denmark and Sweden in 1993, there is a large variation in childcare prices, with a higher average level in Sweden than in Denmark. Compared to many other countries outside Scandinavia, the prices are fairly low.

Figure 3. Monthly childcare prices. Sweden $(n=21018)$ and Denmark $(n=8117)$.

SWEDEN

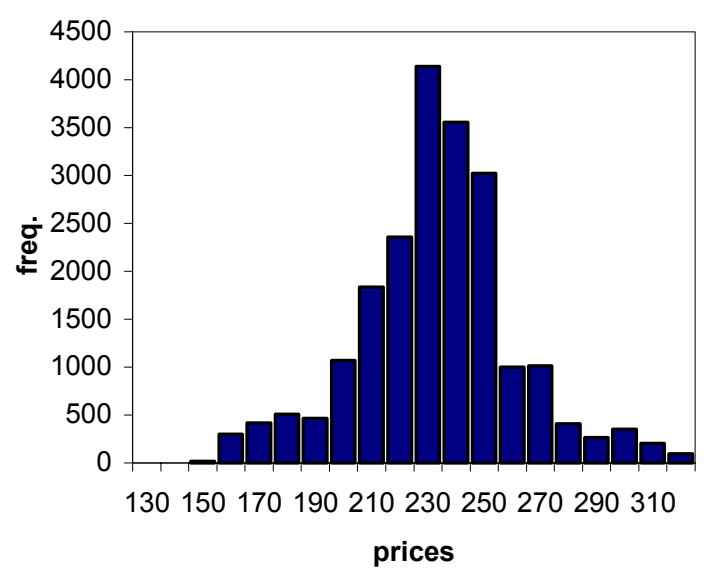

DENMARK

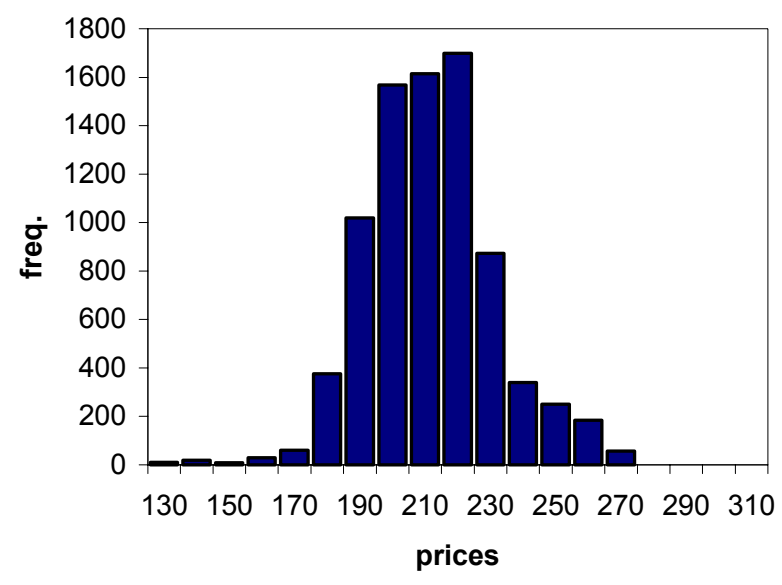


Municipalities are responsible for arranging childcare. There are various forms of public childcare programs: childcare centres, family childcare and after school homes. Beside the public services, there also exist private childcare services (some of them are publicly supported), but the amount of private services is considerably less than in other non-Nordic countries. The public childcare system is universal and based primarily on children's needs, and therefore it is very common for children to attend publicly provided childcare even though the parents are not working.

Despite the high coverage of publicly provided childcare in both countries, there is an excess demand for childcare places in many municipalities. There are more or less formal queuing systems in many municipalities implying that parents either have to extend their leave of absence or use private childcare. There is no systematic information on queues to public childcare. Furthermore, a small market for untaxed private childcare exists, but there is fairly little information on the amount and prices of privately provided childcare. One reason that private childcare is seldom used and there is a lack of exact information is that private childcare is almost always untaxed and part of the underground sector because of the high levels of VAT and income taxes in Denmark and Sweden. If private childcare was produced in the formal (taxed) sector and without subsidies, the prices would be extremely high compared to publicly provided care. However, parents also seem to prefer public childcare for quality reasons.

\subsection{Other Family Policy Regulations}

The law guarantees a job security which entails the same or a comparable position upon the parent's return from leave. In both countries, it is illegal to fire a parent on parental leave. In Sweden, there is a job protection period of 18 months for parents of a newborn, and furthermore parents are legally entitled to work shorter hours until the eighth birthday of the child, with a corresponding reduction in wages, in both the public and private sectors. In Denmark, this is only the case for publicly employed parents.

In both countries, a scheme for care days exists. In Denmark, the publicly employed have a right to 10 care days annually with full pay, which can be used if the child is ill, for visits at the doctor etc. Since 1998, some groups in the private sector have also got the right to care days (14 days with full pay). In Sweden, there is a parallel care day scheme. A parent has a right to 60 days of care annually if the child is ill up to its $12^{\text {th }}$ birthday. 
Finally, in both countries the option of part-time work has been available for most women. The part-time frequency has been high in both countries, but in the latest decades it has dropped considerably in Denmark, but not in Sweden. In 1983, 43\% of all Danish employed women were part-time employed while in 2000 the frequency was only 17\%. Women with young children tend work longer hours than women without children, see Smith (1998). In Sweden, $46 \%$ of the mothers and about 6\% of the fathers of young children worked part-time in 1998 (SCB, 2001).

\section{$4 \quad$ Model}

Our intention is to estimate parallel models of the effects of different family policies on job retention of Danish and Swedish mothers, controlling for other individual and family characteristics that are likely to affect retention. In deriving a model that describes the decision to re-enter the labour market after childbirth, we assume that the fertility decision has already been made and the decision whether to resume employment depends on the expected utility over the lifecycle at each point of time. A formal theoretical model based on this approach is found in Ondrich et al. $(1998,1999)$.

Based on an inter-temporal plan, the timing of job retention may be described by a model where the mother in each period evaluates her expected utility of returning to work $\left(V_{W}(t)\right)$ with her expected utility of staying at home $\left(V_{M}(t)\right)$ for one more period. The expected utility from returning to work includes the wage effects from human capital depreciation, forgone training and the potential wage effects of loosing the current job and thus probably loosing a firm-specific human capital. The expected utility from staying at home one more period depends on individual preferences, the family situation (e.g. the existence of other children) and the rate of compensation while on leave. The model by Ondrich et al. does not explicitly include prices and availability of alternatives to a mother's time with respect to care for the child, i.e. public or private childcare, and the price and availability of the father's time, but these variables may be added to the model. The presence of a newborn is likely to increase $V_{M}$ strongly within the first months or years, but as children grow they become less time-intensive (but more goodsintensive), and thus the utility of staying at home one more period is likely to fall. The mother will return to work at the first $t$ for which $V_{W}(t)>V_{M}(t)$. Ondrich et al. show that the probability of returning to work in a given period is a negative function of the time until the leave period expires and the compensation rate. 
In analyzing the return to work after childbirth, we use a continuous time duration model. A set of parameters is used to generate probabilities of events occurring in intervals of different lengths. The intention is to consider the impact of family policies (duration of and compensation in maternal and parental leave, prices and availability of childcare) on job retention, controlling for other aspects that might affect their preferences, such as education, age, marital status and having other young children. The career break due to childbirth is measured as a period on compensated parental leave, calculated as full-day equivalents and measured in weeks on parental leave. The probability of ending a career break and resuming employment is estimated using a Cox proportional hazard model of the duration of parental leave. The advantage of this method is that it does not require any a priori assumption about the probability distribution to represent survival times. The model is written as

$h_{\mathrm{i}}(t, X)=\lambda_{0}(t) \exp [X(t) \beta]$

where $h_{\mathrm{i}}(t, X)$ represents the hazard for individual $i$ at time $t, \lambda_{0}(t)$ is the baseline hazard function that is left unspecified, i.e. we use a semi-parametric approach, and $X(t)$ represents a vector of time invariant and time-varying covariates and $\beta$ is a vector of parameters. ${ }^{2}$

A principal drawback when applying the basic Cox proportional hazard model is that it assumes for any two individuals that the ratio of the hazards is constant over time. However, there are various ways to test whether this proportionality assumption holds, for example with the Schoenfeld residuals method used here. Another drawback with the model is that it does not account for unobserved heterogeneity. Individuals usually differ in ways that are not fully captured by the model. As pointed out in numerous studies, estimation of hazard models that do not control for unobserved heterogeneity may result in biased estimates of the parameters (Heckman and Singer, 1985). For example, individuals with unobserved characteristics in the form of preferences for market work and career ambitions will probably return to work before individuals who are less committed to work. Thus, the observed probability of returning to work, conditional of not having returned yet, i.e. the hazard, will tend to decline with the length of the spell simply because of a sorting effect where more and more individuals with unobserved

\footnotetext{
2 Since the option of part-time work may play an important role for the decision to return to the labour market, it would have been interesting to see whether mothers end up to a part-time or full-time employment after the parental leave spell by estimating a competing risks model, which allows us to estimate destination-specific hazard functions. Unfortunately, the information in our data sources on part- and full-time states after childbirth is incomplete, and therefore we are not able to apply a competing risks approach.
} 
characteristics for non-work will dominate the group of individuals still on leave. On the other hand, along the lines of the human capital theory the heterogeneity with respect to the preference for work is at least partly observable. Differences in human capital endowments are reflected in differences in the level of education and in labour market experience. Therefore, we could expect to capture the group of women with a higher preference for work by controlling for these observable characteristics if schooling attainment is a function of ability and motivation and other unobserved characteristics, see Figure 1.

\section{$5 \quad$ Data and Descriptive Statistics}

To study career interruptions due to parental leave, we use register data containing information on parental leave periods of all parents and compensation levels, conducted by the National Insurance Board, Sweden. These data is a supplement to the large longitudinal LINDA database ${ }^{3}$ which has register-based information on income and taxes with a rich array of individual and family characteristics. The LINDA data are representative data on the Swedish population and contain information on about 300,000 households annually. Due to the panel property of the data, we are able to follow individuals from the year 1992 up to 2000. In total, there are 20,573 observations (childbirths) in the Swedish sample. Since some women experience more childbirths during the observation period, the same mother may have more birth records in the sample.

The parental leave data contain information on all children and their parents who have taken parental leave during the child's first eight years. The data have records on periods when taking leave, level of compensation, number of days with compensation and rate of compensation. These data cover the years 1993-2001 (June). The key variables of the study are collected from both the basic LINDA database and the supplementary data basis. Since the idea is to study the length of career breaks, we focus on the mothers who were employed, self-employed or unemployed prior to childbirth. In order to be able to follow mothers at least 15 months after childbirth, the birth cohorts considered are 1993-1998. The records for mothers' and fathers' characteristics are collected from a year before and the information about the re-entry to the labour market from a year after the parental leave spell. We only include birth observations where we have observations on both fathers and mothers.

\footnotetext{
${ }^{3}$ Longitudinal Individual Data (LINDA) is a joint endeavour between the Department of Economics at Uppsala University, The National Insurance Board (RFV), Statistics Sweden and the Ministries of Finance and Labour. The data have been collected systematically since 1960 .
} 
In Sweden, mothers can take parental leave with a $25,50,75$ or $100 \%$ compensation rate. Parental leave periods are then converted as full-day equivalents. Nevertheless, the majority $(92 \%)$ of all mothers take the leave with a 100\% cover. Mothers are followed until they resume work or stop their parental leave schemes. A career break, the dependent variable, is counted as the time in weeks between the first day of the parental leave period and the last one during the first fifteen months after the childbirth. Even though the majority of the mothers take their period of leave very concentrated right after the birth, some women choose to return to employment before their maternity leave has expired.

The Danish sample is selected from the Danish Longitudinal Panel Database which is a random register-based sample selected by Statistics Denmark. ${ }^{4}$ The sample is a representative panel sample, which covers each of the years 1976-1997 for about 300,000 individuals (5\% of the Danish adult population). For this study, we have selected all women in the master sample who gave birth to at least one child during the period 1993-1996 and who were labour market participants prior to childbirth. For these women, additional register information from "The integrated Social Statistics" owned by Statistics Denmark is merged to the master sample. The register includes weekly or monthly information on all types of public income transfers and weekly information on participation in different leave schemes. The first year included in this register was 1993, and at the time of selecting the sample, the last available year was 1997. Therefore, we restrict the selected sample to children born during the period 1993-1996 in order to reduce the number of right-censored observations. In the estimations only observations where both parents are observed are included. In total, there are 9,378 observations (childbirths) in the Danish sample.

Based on the information from the "The integrated Social Statistics", we construct spells of career breaks related to each childbirth. A spell is defined as an unbroken period out of the labour market, either in maternal leave, parental leave or childcare leave, or out of job without being in any scheme. The spell ends when the woman starts to work. From the registers in Statistics Denmark, we get additional information on the fathers of the children who are born in the master sample during 1993-1996. Thus, we are able to construct household information by combining the additional information on fathers with the sample of mothers. The background information is collected during the years 1992-1996 since a number of the explanatory variables are defined by their value during the year prior to birth.

\footnotetext{
${ }^{4}$ Documentation of the $5 \%$ sample is found on www.cls.dk.
} 
The Danish and Swedish mothers are classified into three different samples according to the order of the child. The first sample consists of mothers who give birth to their first child, the second sample contains the mothers who are having their second child and the third sample contains the higher order births. Adopted children and multiple births are excluded. Further, we only choose mothers who have a partner, either married or cohabiting.

Due to the differences in the constructions of the data, the Danish and Swedish observations (events) are collected in different ways. In both samples, we avoid left-censoring by conditioning on parents who get a baby within the observation period. In the Swedish case, mothers are followed about fifteen months after the childbirth or until they re-enter the labour market if it happens before. Right censoring occurs after the observation period if the mother has not returned to the labour market, which is the case if she has a new period of parental leave, starts studying or stays at home caring the child. In the Danish case, the sample is selected from a random sample of mothers who had a child during the period 1993-1996. These women are observed weekly during the period. A spell is right-censored if the woman is still on maternal, parental or childcare leave at the end of the observation period, i.e. ultimo 1997. Table 1 shows the sample means of parental leave durations for mothers and fathers in Denmark and Sweden, distributed by birth order.

Table 1. The mean duration of parental leave periods of mothers and fathers in weeks and the share of fathers taking parental leave.

\begin{tabular}{l|c|c|c}
$\begin{array}{l}\text { SWEDEN 1) } \\
\text { Observation period 1993-98 }\end{array}$ & First child & Second child & $\begin{array}{c}\text { Higher } \\
\text { order }\end{array}$ \\
\hline $\begin{array}{l}\text { Parental leave taken by a mother } \\
\text { (duration in weeks) }\end{array}$ & 40.2 & 42.5 & 43.1 \\
\hline $\begin{array}{l}\text { Parental leave taken by a father } \\
\text { (duration in weeks) }\end{array}$ & 4.4 & 3.8 & 4.0 \\
\hline $\begin{array}{l}\text { Percentage of fathers who takes a } \\
\text { leave period }\end{array}$ & $77 \%$ & $69 \%$ & $72 \%$
\end{tabular}

\begin{tabular}{l|c|c|c}
$\begin{array}{l}\text { DENMARK } \\
\text { Observation period 1993-96 }\end{array}$ & First child & Second child & $\begin{array}{c}\text { Higher } \\
\text { order }\end{array}$ \\
\hline $\begin{array}{l}\text { Parental leave taken by a mother } \\
\text { (duration in weeks) }\end{array}$ & 30.6 & 31.4 & 32.5 \\
\hline $\begin{array}{l}\text { Parental leave taken by a father } \\
\text { (duration in weeks) }\end{array}$ & 1.3 & 1.3 & 1.2 \\
\hline $\begin{array}{l}\text { Percentage of fathers who take a } \\
\text { leave period }\end{array}$ & $59 \%$ & $59 \%$ & $58 \%$ \\
\hline
\end{tabular}

1) For Sweden, the observation period is restricted to the first 15 months after childbirth.

The average leave period of Swedish mothers was about 10 weeks longer than the period of Danish mothers. The average leave period for the first child was about 40 weeks in Sweden and 
30 weeks in Denmark, while the maternal leave period tends to increase slightly in both countries, the more children the mother already has. On average, a Swedish father had a leave period of 4 weeks during the period 1993-1998 while Danish men spent much less time on paternal leave, only about 1.3 weeks per child. This partly reflects that a larger proportion of Danish men (about $40 \%$ ) do not at all take up any leave when they become a father. For Sweden, this figure is only about $27 \%$.

In Section 6, we model the duration of mothers' leave periods, but we do not model a joint model of both parents' leave periods due to data restrictions. When analyzing the impact of family policies on the duration of mothers' career breaks, the optimal variable to include would be the leave period targeted to fathers and mothers. Since the entitlement period for mothers is constant both in Sweden and Denmark during the observation period, we are not able to include the entitlement period of the mother as an explicit family policy variable. However, during the observation period, 1993-1998, the Swedish father quota was extended, and the variation allows us to use this variable as a covariate. For the Danish sample, we use the length of a parental leave actually taken by the father, because there was no variation in the Danish paternal leave period during the observation period. The actual take-up of parental leave may be endogenous in the model, because the duration of both parents' spells may be determined in a simultaneous process. We are not able to control for this problem in the current model because we do not have access to valid instruments in the sample. This, of course, implies that our results may overstate the substitution effects between the parents, and that the causality may run both ways.

Another key explanatory policy variable is the compensation rate during the leave period. As described above, the rate of compensation is not constant during the mandated leave in either of the countries but decreases stepwise. Based on register information on hourly wages, duration and timing of leave periods and supplementary information on the compensation rules, we are able to construct for each individual a time-varying variable representing the compensation rate that she receives during the leave of absence. The compensation rate is defined as the hourly compensation divided by the hourly market wage that the woman had prior to the leave period. The compensation rate is only calculated for the fathers and mothers where we have observations on their wage income. The calculated compensation rates are shown in Figure 2.

Additional information on the local prices of publicly provided childcare is included in the sample. We include information on prices in 1993 in each of the 273 Danish municipalities and in 
about 150 Swedish regional areas, see Figure 3, which showed the sample distribution of monthly prices of publicly provided childcare for children aged 0-2 years. ${ }^{5}$ In order to control for the rationing of the public childcare, we also add an indicator variable for those municipalities where the availability of public childcare is limited.

Other control variables (time-constant) are collected from the LINDA data (Sweden) and the 5\% sample (Denmark) a year prior to childbirth. These are age, level of education, years of labour market experience, sector of employment, employment status, marital status, total income of a household and number and ages of other children. We have the respective information about fathers, too.

The labour market status before childbirth will possibly affect the timing of the labour market reentry. For women without a permanent job, the employment status during pregnancy might be highly relevant. Thus, we include an indicator variable for whether a woman was unemployed before the childbirth. We also control for sector of occupation prior to birth. The sector of occupation is: State, municipality, private employer or unemployed. The hypothesis is that those employed in the public sector might return to work earlier due to wider opportunities of combining work and parenthood (more flexible work schemes, e.g. part-time work).

The timing of paid work is hypothesized to depend on a woman's opportunity cost of working for pay relative to her opportunity cost of staying home. The opportunity cost of staying home depends on a set of buman capital variables. Those who have a higher opportunity cost will be expected to return to work sooner. In view of that, the age at childbirth has a negative effect on job-retention since younger women have longer future work horizons and therefore would lose more from a career interruption. Also, women who have invested more in human capital, having higher educations and more work experience may have more to lose when staying out of employment. To capture these effects, we use age, attained level of education and years of work experience as covariates. The level of education is defined by four categories: primary school, high school or vocational school, short university degree and long university degree. The lowest level of education is used as a reference group in the estimations. The family situation is captured by variables on age of children in the household and marital status. Family income may play an

\footnotetext{
${ }^{5}$ There are about 238 municipalities in Sweden, but the information of prices is aggregated to regional prices. For Denmark, we use prices at municipal level. For each child in the sample, we assign the monthly price of childcare in the concerned area (municipality or for Sweden a larger area), whether or not the child is in publicly provided childcare after the leave period of the parents.
} 
important role in the timing of women's employment after childbirth. To capture this effect, we use family income as a covariate.

To control for the macro economic trends during the period of interest, the yearly national unemployment rate is used as a covariate. Higher unemployment rates are expected to lengthen the time out of work. All the monetary values are expressed in Euros in 2000 prices. In Appendix, Tables A1-A3 summarize the descriptive statistics for each of the three sub-samples, i.e. $1^{\text {st }}$ birth observations, $2^{\text {nd }}$ birth observations and $3^{\text {rd }}$ or more births observations.

\section{$6 \quad$ Results and Policy Simulations}

The results concerning the effects of family policy variables on the duration of Danish and Swedish mothers' parental leave are shown in Table 2. In Table A4 in the Appendix, the full estimation results including all the estimated coefficients are presented. In general, the effects of non-family policy variables show the expected results, for instance the higher the education of the mother, the higher is the hazard rate, i.e. shorter a duration of the leave period. In both countries, women employed in the public sector tend to have longer duration of their leave periods in Sweden and Denmark, probably reflecting a more family-friendly environment in the public sector. However, below we focus on the family policy variables, compensation rates for mothers, fathers' leave periods, childcare prices and availability of public childcare.

In both countries, a higher compensation rate significantly tends to lengthen the career break for mothers having their first and second child, and in Sweden the compensation rate is also negatively significant for the third child. The largest effect is found for the first child in Sweden while the effect is smaller for the second and third child in Sweden. In Denmark, the large numerical effect also holds for the second child. The potential length of the father's leave period reduces the leave period of the mother significantly in Sweden, while for Denmark the actual duration of the father's leave period also has a positive effect on the hazard rate for re-entering the labour market. However, it should be kept in mind, that the definition of this variable is measured differently for Sweden and Denmark, and for Denmark there may be simultaneity problems which may imply that the numerical size of the estimated effect is overstated. 
Table 2. Selected results from country-specific estimations of a proportional hazard model of re-entering the labour market after childbirth according to birth order: The effects of family policy variables.

\begin{tabular}{|c|c|c|c|}
\hline VARIABLE & $\begin{array}{c}1^{\text {ST }} \text { CHILD } \\
\text { PARAMETER } \\
\text { ESTIMATE } \\
\text { (STANDARD ERROR) }\end{array}$ & $\begin{array}{c}2^{\text {ND }} \text { CHILD } \\
\text { PARAMETER } \\
\text { ESTIMATE } \\
\text { (STANDARD ERROR) }\end{array}$ & $\begin{array}{l}3^{\text {RD }} \text { CHILD } \\
\text { PARAMETER } \\
\text { ESTIMATE } \\
\text { (STANDARD } \\
\text { ERROR) } \\
\end{array}$ \\
\hline \multicolumn{4}{|l|}{$\begin{array}{l}\text { Family policy regimes: } \\
\text { DENMARK }\end{array}$} \\
\hline Compensation rate & $\begin{array}{c}-0.595 * * * \\
(0.121)\end{array}$ & $\begin{array}{c}-0.599 * * * \\
(0.139)\end{array}$ & $\begin{array}{c}-0.071 \\
(0.213)\end{array}$ \\
\hline Father's leave & $\begin{array}{c}0.053 * * * \\
(0.009)\end{array}$ & $\begin{array}{c}0.062 * * * \\
(0.013)\end{array}$ & $\begin{array}{c}0.026 \\
(0.017)\end{array}$ \\
\hline Childcare price & $\begin{array}{c}0.032 \\
(0.103)\end{array}$ & $\begin{array}{l}-0.031 \\
(0.104)\end{array}$ & $\begin{array}{l}-0.183 \\
(0.182)\end{array}$ \\
\hline Big city & $\begin{array}{l}-0.258 \\
(1.591)\end{array}$ & $\begin{array}{l}-1.282 \\
(2.063)\end{array}$ & $\begin{array}{l}-0.483 \\
(4.786)\end{array}$ \\
\hline Childcare price $*$ city & $\begin{array}{c}0.145 \\
(0.734)\end{array}$ & $\begin{array}{c}0.597 \\
(0.951)\end{array}$ & $\begin{array}{l}0.188 \\
(2.227)\end{array}$ \\
\hline \multicolumn{4}{|l|}{ SWEDEN } \\
\hline Compensation rate & $\begin{array}{c}-0.638 * * * \\
(0.197)\end{array}$ & $\begin{array}{c}-0.235 * \\
(0.103)\end{array}$ & $\begin{array}{c}-0.343 * * \\
(0.113)\end{array}$ \\
\hline Father's leave & $\begin{array}{c}0.036^{* *} \\
(0.013)\end{array}$ & $\begin{array}{c}0.040 * * * \\
(0.007)\end{array}$ & $\begin{array}{c}0.045^{* * *} \\
(0.008)\end{array}$ \\
\hline Childcare price & $\begin{array}{l}0.024 \\
(0.087)\end{array}$ & $\begin{array}{c}-0.113 * * \\
(0.043)\end{array}$ & $\begin{array}{l}-0.076 \\
(0.049)\end{array}$ \\
\hline Big city & $\begin{array}{l}-0.512 \\
(0.873)\end{array}$ & $\begin{aligned}-2.578 * * * \\
(0.490)\end{aligned}$ & $\begin{aligned}- & 1.650 * * \\
& (0.565)\end{aligned}$ \\
\hline Childcare price $*$ city & $\begin{array}{l}0.150 \\
(0.367)\end{array}$ & $\begin{array}{c}1.053 * * * \\
(0.206)\end{array}$ & $\begin{array}{c}0.688 * * \\
(0.237)\end{array}$ \\
\hline Controls for : & & & \\
\hline $\begin{array}{l}\text { Labour market status } \\
\text { Human capital variables } \\
\text { Family situation } \\
\text { Macroeconomic variables } \\
\text { Number of observations }\end{array}$ & yes & yes & yes \\
\hline DENMARK & 3675 & 3172 & 1270 \\
\hline SWEDEN & 3300 & 9756 & 7516 \\
\hline
\end{tabular}

Significance levels: $*<0.05, * *<0.01, * * *<0.001$.

Childcare prices also show the expected sign for the second and higher order births, but the effect is only significant for the second birth sample in Sweden. For Denmark, neither the coefficients of childcare prices, nor the coefficients reflecting queuing systems (approximated by the indicator variable 'big city') are significant. This result may not be very surprising since the prices of childcare are relatively low in Denmark, and the coverage of publicly provided childcare is fairly good, though waiting lists for public childcare do exist. For Sweden, the queuing effects seem to dominate price effects, and prices as well as availability of childcare seem to be much more important for second and third child compared to first child, probably reflecting that the importance of these factors increases with number of children who have to attend childcare if the mother works. The effect of childcare prices is negative only if the availability is good measured by the 'big city' indicator as a proxy for queuing systems (the interaction term shows a positive sign). For Sweden, the results indicate that availability of public childcare is more important to 
the job retention decision for the second and third sample than the price. It may well be the case that many mothers have to postpone the job retention due to queuing. In Sweden, not only publicly provided childcare may be difficult to obtain. Also the availability of informal care, such as that provided by grandparents, friends and neighbours in a non-market setting, may be more difficult to get if a family lives in a big city where these informal networks are weaker.

The significance of estimated coefficients gives some indication of the importance of family policy instruments on mothers' labour supply decisions around childbirth. However, in order to evaluate the numerical size of these, we pursue some policy reforms and apply the new rules to the Danish and Swedish samples. To predict the length of the career break, we replace a set of family policy covariates with the new ones and evaluate the survivor estimates for a "typical" case. In order to be able to obtain predictions the time-dependent covariate, the rate of compensation, is changed to a time-constant replacement rate that will only depend on previous income, sector of employment (Denmark) and the year in question (Sweden). For the Swedish case, the mandated parental leave period for mothers is added to the equation as an explanatory variable to be able to control for that in simulations.

The survival probability, $S(t)$, at time $t$ for an individual with covariate values $\mathbf{x}$ can be written as

$S(t)=\left[S_{0}(t)\right]^{\exp \left(\boldsymbol{\beta}_{\mathbf{x}}\right)}$

where $S_{0}(t)$ is the baseline survivor function. After estimating $\beta$, we get an estimate of $S_{0}(t)$ by a non-parametric maximum likelihood method. With that estimate we generate the estimated survivor function for a "typical" case by substituting her characteristics and the suggested policy reforms in the equation (2). We simulate the policy changes for the two samples of Danish and Swedish $2^{\text {nd }}$ child mothers, since in overall the family policy instruments tended to be more significant for $2^{\text {nd }}$ child mothers in both countries (in Denmark the effects were insignificant for $3^{\text {rd }}$ child while in Sweden the childcare variables were insignificant for $1^{\text {st }}$ child).

First, we apply the main features of the Danish system but we keep the entitled days for mothers constant (the compensation rate is set to either 1.0 for the public sector or 0.7 for the private sector, father's leave is set to 2 weeks, big city assumes the value of 0 indicating no availability problems of childcare and childcare prices are reduced slightly). In the second policy suggestion, we apply more equal parental leave schemes that share the responsibility more even between the 
parents and predict the effect on the length of the mothers' career breaks. The parental leave quota for fathers is set to four months with everything else unchanged, i.e. maintaining the idea of flexibility. The third policy reform tests the effect of a free and perfectly available childcare. Lastly, we test the effects of different compensation rates, with a full pay and with a lower rate of compensation.

The last row of Table 3 shows the predicted lengths of the career breaks after the suggested changes in family policy schemes. According to the results, Swedish mothers having their $2^{\text {nd }}$ child would react somewhat to these changes. When the Danish system is applied to the Swedish sample, the simulations indicate that women in the private sector with the low compensation rate would have a one-week shorter career break, which is not much out of the total of 330 days of leave. If there were full wage compensation as it is the case in the public sector in Denmark, Swedish women having their second child would take 2 weeks' longer leave. The second policy reform gives fathers a 16-week long parental leave all other things unchanged. This reform would decrease the career break for the mother by 4 weeks. The result could imply that if we tried to promote equality between males and females in the labour market, more leave should be directed explicitly to fathers.

Table 3. Results from policy simulations for a typical household. The predicted length of the career break under different family policy rules applied to the Swedish sample of mothers having the $2^{\text {nd }}$ child..$^{1}$

\begin{tabular}{l|c|c|c|c|c} 
FAMILY POLICY RULES & 'Swedish rules' & 'Danish rules' & $\begin{array}{c}\text { 'Swedish rules' } \\
\text { but:16 weeks of } \\
\text { leave for fathers }\end{array}$ & $\begin{array}{c}\text { 'Swedish rules' } \\
\text { but: } \\
\text { no childcare fees, } \\
\text { availability }\end{array}$ & $\begin{array}{c}\text { 'Swedish rules' } \\
\text { but: } \\
\text { compensation } \\
\text { rates: } 1.0 / 0.5\end{array}$ \\
\hline Compensation rate & 0.8 & $0.7 / 1.0$ & 0.8 & 0.8 & $1.0 / 0.5$ \\
\hline Father's leave (weeks) & 4.0 & 2.0 & 16.0 & 4.0 & 4.0 \\
\hline Childcare fee & 2.5 & 2.0 & 2.5 & 0 & 2.5 \\
\hline Childcare availability & 0 & 1 & 0 & 1 & 0 \\
\hline Duration of leave & $\mathbf{4 1}$ & $\mathbf{4 0 / 4 3}$ & $\mathbf{3 7}$ & $\mathbf{3 9}$ & $\mathbf{4 2 / 3 8}$
\end{tabular}

1) A typical household is defined as a household with a mother having average characteristics for continuous variables and modal values for indicator variables. Thus, the mother is 32 years old, she is married and she has another child aged 0-2 years. She has 7 years of labour market experience, a long university degree, and she is employed in the public sector (state). Her husband takes 4 weeks' parental leave. The family income is $€ 33$ '.

The third reform involves changes in childcare availability and its price. As we saw earlier, we cannot test the price effect separately, because the restrictions in the supply side of the childcare may dominate the price effect. Free and perfectly available childcare would result in two weeks' shorter parental leave periods for mothers, when the quality aspects of childcare are not considered. Finally, we assess the effects of different rates of compensation. According to the simulations mothers would increase their leave by one week if they had full wage compensation 
during maternal leave. If the compensation was decreased to 0.5 , they would return three weeks sooner to the labour market.

The results from these policy reforms applied to the Danish sample are seen in Table 4. We use a compensation rate of 0.8 for the 'standard person', despite the compensation rate is typically either 1 (public sector) or lower than 0.8 (private sector). When applying the Swedish 'standard rules', there seems to be no effect on the duration of Danish mothers' leave periods. The same is the case in Column 4, where we simulate the effect of free childcare and better availability of childcare. If the father took a leave period of as much as 16 weeks, i.e. an increase of 14 weeks compared to the base regime in Column 1, this would reduce the mother's leave period by about 2 weeks. Since we have not corrected for potential endogeneity of father's take-up of the leave period, this estimate is expected to be an overestimate of the potential effect. In this light, and compared to the Swedish result where Swedish mothers were simulated to reduce their maternal leave by 4 weeks if the potential father leave was extended from 4 to 16 weeks, Danish women seem to be very difficult to move with respect to the duration of their leave. Also the effect of making childcare for free or changing the compensation rate for the mothers have virtually no effects on the duration of Danish mothers' leave periods according to the simulations.

Table 4. Results from the policy simulations for a typical household. The predicted length of a career break under different family policy rules applied to the Danish sample of mothers having the $2^{\text {nd }}$ child. ${ }^{1)}$

\begin{tabular}{l|c|c|c|c|c} 
FAMILY POLICY RULES & 'Danish rules' & 'Swedish rules' & $\begin{array}{c}\text { 'Danish rules' } \\
\text { but: } 16 \text { weeks of } \\
\text { leave for fathers) }\end{array}$ & $\begin{array}{c}\text { 'Danish rules' } \\
\text { but: no childcare } \\
\text { fees, availability }\end{array}$ & $\begin{array}{c}\text { 'Danish rules' } \\
\text { but: } \\
\text { compensation } \\
\text { rates: } 1.0 / 0.5)\end{array}$ \\
\hline Compensation rate & 0.8 & 0.8 & 0.8 & 0.8 & $1.0 / 0.5$ \\
\hline Father's leave (weeks) & 2.0 & 4.0 & 16.0 & 2.0 & 2.0 \\
\hline Childcare fee & 2.0 & 2.5 & 2.0 & 0 & 2.0 \\
\hline Childcare availability & 1 & 0 & 1 & 1 & 1 \\
\hline Duration of leave & $\mathbf{2 9}$ & $\mathbf{2 9}$ & $\mathbf{2 7}$ & $\mathbf{2 9}$ & $\mathbf{3 0} / \mathbf{2 9}$
\end{tabular}

1) A typical household for the Danish sample: the mother is 30 years old, she is married and has another child aged 0-2 years. She has 3 years of labour market experience, a high-school degree and she is employed in the public sector (municipality). Her husband takes one week of parental leave. The family income (excluded the mother's labour income) is $€ 42$ '.

Thus, the Swedish mothers seem to be much more sensitive to policy changes than Danish mothers. Danish mothers tend to use exactly the number of weeks which they are entitled to immediately after childbirth. Especially the reactions to changes in the fathers' leave periods differ between the two countries. This may reflect more differences between Denmark and Sweden. Firstly, the Danish schemes are much more inflexible than the Swedish schemes and mothers could not to far the same extent than Swedish women 'save' part of their maternal leave for use in a later period, and then let the father take over for a period after childbirth, i.e. allow 
substitution between parents' time. Second, it may reflect that for a long period there has been much more political focus on shared responsibility of the parents and fathers' take-up of parental leave. Parents may tend to adopt the rules as norms which conduct their behaviour. Further, as shown in Figure 2, the compensation rate of Danish fathers tends to be much lower than that of Danish mothers (because a much larger proportion of the fathers are employed in the private sector while more than half of the mothers are publicly employed). Thus, the much lower paternal compensation rates may imply that Danish parents are to some extent 'caught' in a corner solution, where marginal changes of other policy rules have no effect on the behaviour of the majority of the parents.

\section{$7 \quad$ Conclusions}

Sweden and Denmark are countries with a high participation rate of mothers, and a relatively stable fertility rate which has not dropped dramatically during the latest decades as in most other European countries. Our analysis shows that this position has been reached by using different strategies, in Sweden by introducing very flexible parental leave schemes and a lower coverage of and less subsidized publicly provided childcare. Compared to Sweden, the leave schemes in Denmark have been very inflexible, giving strong incentives to mothers' take-up of parental leave in most households, while on the other hand the public investments in publicly provided and subsidized childcare.

This study investigates the effects of different family policy regimes on the job retention of Danish and Swedish mothers, controlling for other individual and family characteristics that are likely to affect retention. Here we focus only on mothers who had a partner and participated in the labour market and interrupted their careers due to childbirth during the 1990s. Our analysis takes advantage of the availability of comparable longitudinal data, which allow us to estimate parallel models across the countries. The probability of ending a career break and resuming employment is estimated using a Cox proportional hazard model.

Compared to previous research, this study applies the latest and more representative data. So far, only a few studies have addressed the impact of family policies on the return to work, positive exceptions are the studies of Rönsen and Sundström (1996) and Gustafsson et al. (1996), where they compare the determinants of the length of a career break in connection with childbirth between Sweden and some other European countries. The novelty and the contribution of this study are to compare the two Scandinavian countries with similar welfare state ideologies with 
high labour force participation of mothers but with different parental leave regimes. Moreover, here we also take other family policy regimes explicitly into account including the childcare availability and prices.

Our empirical analysis shows that to a large extent the paid parental leave mandates determine the rate of return to employment. However, economic factors also have a clear effect on the decision to return from leave. A lower compensation rate prolongs the duration of the leave period. Fathers' parental leave take-up plays an important role in the timing of women's employment after childbirth: the longer leaves for fathers the shorter time-off work periods for mothers. For Sweden, the price of publicly provided childcare affects the decision to return to the job in areas where childcare is available, i.e. where queuing systems are not a typical problem. In Denmark, where childcare prices are generally lower, childcare prices are not found to affect the decision to return to work.

A number of policy simulations based on the estimated hazard functions for the two countries are performed, in order to test how much these changes would affect the mothers' parental leave take-up. The policy changes include applying the Danish rules to the Swedish mothers and vice versa, giving fathers more ring-fenced leave, providing an access to a free childcare and varying the rate of compensation. For Sweden, each of these changes results in some reactions in mothers' parental leave take-up, but the most interesting result is that when fathers were given a parental leave of 16 weeks, all other things unchanged, the leave for the mother decreased by 4 weeks. This result implies that, if the political ambition is to promote equal career prospects between men and women, more leave should be directed explicitly to fathers. For Denmark, the simulations indicate that even large changes of policy instruments have minor effects on the duration of mothers' leave periods. We explain this empirical evidence by the fact that the Danish leave schemes are much more inflexible compared to the Swedish schemes. The apparently very low level of substitution between the parents' time allocation, compared to Sweden, may reflect that Denmark has not had a tradition for a "father quota" leave period like in Sweden. Further, on average the economic incentives are extremely negative for Danish fathers to take up parental leave, and thus there is yet no tradition in Denmark for the families to consider potential substitution options between the parents' time allocation.

Thus, the much more flexible Swedish system and the more focus on equalization of parents' use of parental scheme compared to Denmark may have implied that to a larger extent Swedish 
parents are actually able or willing to adapt policy changes while Danish parents seem to be stuck in 'corner solutions' where changes of family policies do not really affect their behaviour, either because the Danish parents are too far away from economic conditions where they were actually able or willing to substitute parents' time, or because the labour market does not allow this substitution in practice. Our results clearly show that there is room for policy changes, which might promote both female labour supply and equal role sharing by both parents. 


\section{References}

Datta Gupta, N. and Smith, N. (2002), "Children and Career Interruptions: The Family Gap in Denmark", Economica, 69, pp. 609-629.

Ellingsäter, A. L. (1998), "Dual Breadwinner Societies: Provider Models in the Scandinavian Welfare States”, Acta Sociologica 41, pp. 59 - 73.

Esping-Andersen, G. (2002), A New Gender Contract, Ch. 3 in Esping-Andersen, G., D. Gallie, A. Hemerijk and J. Myles, Why we need a new welfare state, Oxford University Press, Oxford.

Gustafsson, S., Wetzels, C., Vlasblom, J. D. and Dex, S. (1996), “Women’s Labor Force Transitions in Connection with Childbirth: A Panel Data Comparison Between Germany, Sweden and Great Britain", Journal of Population Economics, Vol. 9, pp. 223 - 246.

Heckman, J. and Singer, B. (1985), "Social Science Duration Analysis" in Longitudinal Studies of Labor Market Data, ed. J. J. Heckman and B. Singer, New York: Cambridge University Press, Ch. 2 .

Joesh, J. M. (1994), “Children and the Timing of Women's Paid Work after Childbirth: A Further Specification of the Relationship", Journal of Marriage and the Family 56, pp. 429 - 440.

Joesh, J. M. (1995), "Paid Leave and the Timing of Women's Employment Surrounding Birth", Research Center Working Paper No. 95-10, July. University of Washington, Battelle.

Joshi, H., Macran, S., and Dex, S. (1996), "Employment After Childbearing and Women's Subsequent Labor Force Participation: Evidence from British 1958 Birth Cohort", Journal of Population Economics, Vol. 9, pp. 325 - 348.

Klerman, J. A. and Leibowitz, A. (1990), “Childcare and Women’s Return to Work after Childbirth”, The American Economic Review, 80(2), pp. 284 - 288.

Nielsen, H. S, Simonsen, M. and Verner, M. (2002), "Earnings Effects of Children in a Model with Endogenous Sector Choice", Symposium in Applied Statistics 2002: 14-25.

Paull G., Taylor, J., and Duncan, A. (2002), Mothers' Employment and Childcare Use in Britain, The Institute for Fiscal Studies, London, 2002.

OECD (2001), The OECD Employment Outlook, OECD 2001.

OECD (2002), Babies and Bosses, Reconciling Work and Family Life, OECD 2002.

Ondrich, J., Spiess, C. K., Yang, Q., and Wagner, G. G. (1998), “The Liberalisation of Maternity Leave Policy and the Return to the Work of Childbirth in Germany", IZA DP no. 21, Bonn.

Ondrich, J., Spiess, C. K., Yang, Q., and Wagner, G. G. (1999), "Full Time or Part Time? Parental Leave Policy and the Return to Work after Childbirth in Germany", Research in Labor Economics, 18, pp. $41-74$. 
Rostgaard, T. and Fridberg, T. (1998), "Caring for Children and Older People - A Comparison of European Policies and Practices", The Danish National Institute of Social Research 98:20, Copenhagen.

Rostgaard, T., Christoffersen, M. N., and Weise, H. (1999), "Parental leave in Denmark", in P. Moss and F. Deven (eds.), Parental leave: Progress or piffall?, NIDI/CBGS Publications.

Ruhm, C. and Teague, J. L. (1997), "Parental Leave Policies in Europe and North America", in F. Blau and R. Ehrenberg, eds., Gender and Family Issues in the Workplace, New York, NY: Russell Sage Foundation Press, 1997.

Ruhm, C. (1998), The Economic Consequences of Parental Leave Mandates: Lessons from Europe, Quarterly Journal of Economics, 113, pp. 285 - 317.

Rönsen, M. and Sundström, M. (1996), "Maternal Employment in Scandinavia: A Comparison of the After-birth Employment Activity of Norwegian and Swedish Women", Journal of Population Economics, Vol. 9, pp. $267-285$.

SCB (2001), Lönestatistik, Årsbok 2000, Sveriges Officiella Statistik, Statistiska centralbyrån, 2001.

Skolverket (2002), Barns Omsorg, Rapport 203, www.skolverket.se

Smith, N. (1998), The labour supply in Denmark (in Danish) in N. Smith (ed.), Work, Incentives and Unemployment, Aarhus University Press.

Smith, N., Callan, T., Dex, S., and Vlasblom, J. D. (2003), "Taxation of Spouses: A Cross Country Study of the Effects on Married Women's Labour Supply", Oxford Economic Papers.

Socialdepartementet (2001), Barnafödandet i focus - från befolkningspolitik till ett barnvänligt samhälle, Ds 2001:57.

Waldfogel, J. (1998), "Understanding the 'Family Gap' in Pay for Women with Children", Journal of Economic Perspectives, 12, no. 1, pp. 137 - 56.

Waldfogel, J., Higuchi, Y., and Abe, M. (1999), "Family Leave Policies and Women's Retention After Childbirth: Evidence from the United States, Britain, and Japan", Journal of Population Economics, Vol. 12, No 4, pp. 523 - 546, 1999.

Wenk, D. and Garrett, P. (1992), "Having a Baby: Some Predictions of Maternal Employment around Childbirth", Gender \& Society, 6(1), pp. 49 - 65. 


\section{Appendix}

\section{The Danish and Swedish Family Policies}

\section{Parental Leave Schemes}

\section{Duration of the Leave Schemes}

Sweden has a universal parental leave and benefit coverage. All parents are entitled to the leave, regardless of whether they are participating in the labour force or not. Since 1994, parents have been entitled altogether to 450 days compensated leave per child. The leave can be taken flexibly from 60 days before the expected date of birth until the child is eight years old. Benefits can be used either full-time or part-time or saved and used any time within the entitlement period. The system allows both parents to share the leave and to interrupt the leave in order to save days for later use. Parents are entitled to have 360 days (each have 180 days) parental leave with a compensation level that is related to the income prior to the leave period, and in addition to that a father is permitted to take 10 extra days of leave in connection with childbirth. A parent is allowed to transfer his or her days of leave to the other parent, but 30 days are reserved for him or her only. If the other parent does not use these days, they are lost. In addition to that, parents are allowed to take an extra period of leave of 90 days with only a guarantee level of compensation, a flat rate which is $€ 6.7$ per day. ${ }^{6}$ So, the parental leave for each child amounts to 450 days in total, which can be divided among the parents in a very flexible way. Single parents are entitled to 450 days as well. In the case of multiple births, parents are entitled to an additional 180 days leave.

Denmark has a slightly less universal system compared to Sweden (see, for instance, Rostgaard et al., 1999, for a more detailed description of the Danish leave schemes). Since 1985, mothers who have a regular income during the latest 13 weeks before the birth are entitled to a maternal leave of 4 weeks before the birth ( 8 weeks in some unions in the public sector) and 14 weeks after, plus a parental leave period of 10 weeks until 2002 when the parental leave was extended, see below). This parental leave can be taken either by the mother or the father, but the parents cannot be on leave at the same time. During these 10 weeks, a parent is only allowed to work a few hours weekly. If the parent chooses to work part-time, the benefit is reduced accordingly, and the "nonused" period cannot be saved and used later as in Sweden. Further, a father is entitled to 2 weeks' leave in connection to childbirth. During 1999-2002, the father was entitled to two extra weeks after the 10-week parental leave. These weeks were reserved for the father only and were lost if

\footnotetext{
${ }^{6}$ The guarantee level of compensation is SEK 60 (since 1987). The exchange rate used here is $€ 1=$ SEK 8.6.
} 
he did not use them. During the period 1992-2002, an additional 'childcare leave scheme' was available. The childcare leave scheme allowed both parents, whether employed or unemployed, to take leave for a period of up to 52 weeks for each child aged less than 9 years. ${ }^{7}$ Most parents were entitled to the leave, irrespective of membership of unemployment insurance funds (UI-funds), employment etc. The scheme was changed several times and was abolished completely in 2002, when the parental leave period was extended from 10 to 32 weeks abolished in addition to the 14 weeks of maternal leave just after childbirth. At the same time, the 2 weeks of 'father quota' leave was abolished.

\section{Compensation during the Leave Period}

Sweden: The level of compensation depends on prior earnings. If parents have not been employed a period before childbirth, they are eligible only for a guarantee level of benefits which amounts to $€ 6.7$ per day (since 1987). If the parents were employed, they are entitled to an $80 \%$ replacement of their previous income up to an income ceiling. In some sectors (specified in collective agreements between unions and employers' confederation), the public compensation may be supplemented by the employer to full-wage compensation. Further, there is a so-called "speed-premium" for mothers who intend to have another child soon after the previous child. A mother is guaranteed to have the same level of compensation without returning to employment if there is not more than 30 months in between the childbirths. The main purpose of this rule was to stimulate fertility among Swedish mothers.

Denmark: The compensation during maternal leave depends on the sector of employment. In the public sector, there is full-wage compensation. For the privately employed, the compensation depends on collective agreements between the employers and the unions, and some of them have specified a full pay during maternal and parental leave. ${ }^{8}$ For the groups, which are not covered by these agreements, the compensation is calculated according to the rules of the unemployment insurance benefit system (UI-benefits). The compensation is $90 \%$ of previous earnings up to a maximum. On average, the compensation rate is $60-70 \%$ of former earnings. Since men on average tend to have higher earnings than women, and since more than half of the mothers are entitled to a full pay during parental leave, because they are employed in the public sector, most

\footnotetext{
${ }^{7}$ Thus, more individuals are entitled to childcare leave than to parental leave schemes. Housewives without any regular income are the only group which is not entitled to childcare leave. However, this group constitutes less than $5 \%$ of the population in the age groups concerned. The duration of the childcare leave period depends on the age of a child. If the child is less than 1 year, the entitled period is 26 weeks, and it might be extended to 52 weeks if the employer accepts this extension. If the child is older, the duration is shorter.

8 An increasing number of workers in the private sector are entitled to a full compensation of former earnings. Collective agreements between unions and employers specify that the employers are due to supplement the public benefits. In 2002, all women had a full pay during maternal leave.
} 
households have a strong economic incentive to let the mother use the parental leave period, which can be shared between the parents. The compensation during childcare leave was considerably lower than for the maternal and parental leave periods. Initially, the compensation rate was $100 \%$ of the UI-benefits but it has been reduced several times since 1994, and since 1999 the compensation has been $60 \%$ of the UI-benefits. In 2002, when the childcare leave and parental leave schemes were combined into one scheme, the compensation rate for this extended parental leave period is at the same level as the former childcare leave, i.e. $60 \%$ of the UIbenefits.

\section{Childcare}

Sweden: In autumn 2000, 76\% of children aged 1-5, 67\% of children aged 6-9 and about 7\% of children aged 10-12 attended public childcare (Socialdepartementet, 2001). According to a survey, only about 3\% of 1-5 year-old children were in private childcare (Skolverket, 2002). Day care fees have increased especially during the 1990s because of the dampening economic situation in municipalities and in order to suppress the demand. The fees contributed to $18 \%$ of the total costs in 1999. The payment scheme varies across municipalities although most often the payment is related to the number of children, time used and parents' income. While the time-based fees provide parents with greater opportunities to influence the costs of childcare, they can also cause large marginal effects when a parent increases hours of work, especially single parents. On average, the cost for a two-earner household with two children is $€ 230$ (ranging from $€ 0$ to 467). A completely new payment scheme was introduced in 2002, which is called 'maxtaxa' referring to a payment ceiling (for a respective family the cost will be at maximum $€ 210$ ).

Denmark: About 92\% of all children aged 3-5 and more than half of the children aged 0-2 years attended publicly provided childcare in 1999. As in Sweden, the demand for public childcare is strongly stimulated by large price subsidies to childcare. According to the governmental regulations, parents are not allowed to pay more than $30 \%$ of the variable costs of the childcare place for pre-school children aged less than 7 , i.e. the local governments stand for at least $70 \%$ of the variable cost and additionally all fixed costs. In many municipalities, the subsidies are even larger. Further, there is an additional means-tested subsidy for low-income households. The monthly costs of a childcare place vary between municipalities. The typical monthly cost for a $0-2$ year-old child ranges from $€ 250$ to $€ 300$, while for older children the prices are lower. As in Sweden, expenditure on publicly (or privately) provided childcare is not deducible from taxable income. 
Table A1. Descriptive statistics of the sample of parents, the Swedish (1993-1998) and the Danish (19931996), where the mother gives birth to her first child. All variables related to the market work are records from a year prior to the birth. Monetary values are given in Euros in 2000 prices.

\begin{tabular}{|c|c|c|c|c|}
\hline \multirow[t]{2}{*}{ VARIABLE } & \multicolumn{2}{|l|}{ SWEDEN } & \multicolumn{2}{|l|}{ DENMARK } \\
\hline & MOTHERS & FATHERS & MOTHERS & FATHERS \\
\hline AGE & 29.2 & 33.4 & 27.9 & 30.4 \\
\hline AGE WHEN HAVING THE FIRST CHILD & 29.2 & 30.9 & 27.9 & 30.4 \\
\hline HAVING CHILDREN 0-2 YEARS OF AGE & 0 & 0.00 & 0 & 0 \\
\hline HAVING CHILDREN 3-6 YEARS OF AGE & 0 & 0.01 & 0 & 0 \\
\hline NUMBER OF CHILDREN & 1.0 & 1.09 & 1.0 & 1.0 \\
\hline MARRIED & 0.94 & & 0.31 & 0.33 \\
\hline \multicolumn{5}{|l|}{ EDUCATION (the highest attained level) } \\
\hline ELEMENTARY SCHOOL & 0.05 & 0.11 & 0.18 & 0.19 \\
\hline HIGH-SCHOOL DEGREE & 0.47 & 0.44 & 0.53 & 0.57 \\
\hline BACHELOR'S DEGREE & 0.24 & 0.22 & 0.24 & 0.16 \\
\hline MASTER'S DEGREE (or higher) & 0.24 & 0.23 & 0.05 & 0.08 \\
\hline HOURS OF WORK *) & 1788.4 & 2007.1 & 1425.4 & 1751.8 \\
\hline SHARE WITH FULL-TIME WORK *) & 0.90 & 0.93 & 0.95 & n.a. \\
\hline HOURLY WAGE RATE $(\boldsymbol{\epsilon}) *)$ & 10.9 & 12.9 & 17.0 & 20.0 \\
\hline LABOUR INCOME (€ 10000$) *)$ & 1.85 & 2.23 & 2.34 & 2.98 \\
\hline YEARS OF WORK EXPERIENCE & 7.4 & 11.5 & 6.3 & 9.4 \\
\hline FAMILY INCOME (€ 10 000) & 3.40 & & 3.54 & \\
\hline \multicolumn{5}{|l|}{ SECTOR OF EMPLOYMENT } \\
\hline STATE & 0.11 & 0.14 & 0.06 & 0.06 \\
\hline MUNICIPALITY & 0.38 & 0.13 & 0.34 & 0.06 \\
\hline PRIVATE & 0.48 & 0.67 & 0.59 & 0.86 \\
\hline OTHER & 0.03 & 0.06 & 0.01 & 0.02 \\
\hline LIVING IN A BIG CITY **) & 0.48 & 0.48 & 0.20 & 0.19 \\
\hline \multicolumn{5}{|l|}{ PARENTAL LEAVE } \\
\hline TAKE-UP OF LEAVE (weeks) & 40.2 & 4.4 & 30.6 & 1.3 \\
\hline SHARE OF THE FATHERS HAVING LEAVE & & 77.3 & & 59.0 \\
\hline CHILDCARE FEE $(\boldsymbol{(})$ & 232.0 & & 207.1 & \\
\hline COMPENSATION RATE 1 ***) & 0.83 & 0.78 & 0.78 & 0.55 \\
\hline COMPENSATION RATE2 & 0.79 & 0.75 & 0.49 & 0.37 \\
\hline COMPENSATION RATE3 & 0.14 & 0.17 & & \\
\hline NUMBER OF OBSERVATIONS & 3300 & 3300 & 3675 & 3435 \\
\hline
\end{tabular}

*) For Sweden, the information on hours of work and hourly wage rates are not available for every individual but for about $1 / 3$ of our sample, therefore the mean values are calculated only for those having this information.

For Denmark, the mean values are calculated excluding the self-employed.

**) For Sweden, Stockholm, Göteborg and Malmö areas. For Denmark, Copenhagen, Frederiksberg and Aarhus.

$\left.{ }^{* * *}\right)$ For Sweden, the rate of compensation changes during the parental leave (time-varying variable) and varies across sector of occupation (with an income ceiling), and there have also been changes in the parental leave compensation rules over the years. For Denmark, the rate of compensation varies across sector of occupation, and further there is an income ceiling for compensation. 
Table A2. Descriptive statistics of the sample of parents, the Swedish (1993-1998) and the Danish (19931996), where the mother gives birth to her second child. All variables related to the market work are records from a year prior to the birth. Monetary values are given in Euros in 2000 prices.

\begin{tabular}{|c|c|c|c|c|}
\hline \multirow[t]{2}{*}{ VARIABLE } & \multicolumn{2}{|l|}{ SWEDEN } & \multicolumn{2}{|l|}{ DENMARK } \\
\hline & MOTHERS & FATHERS & MOTHERS & FATHERS \\
\hline AGE & 30.4 & 33.1 & 30.5 & 32.8 \\
\hline AGE WHEN HAVING THE FIRST CHILD & 27.8 & 28.8 & 26.5 & n.a. \\
\hline HAVING CHILDREN 0-2 YEARS OF AGE & 0.25 & 0.24 & 0.55 & 0.56 \\
\hline HAVING CHILDREN 3-6 YEARS OF AGE & 0.64 & 0.64 & 0.36 & 0.35 \\
\hline NUMBER OF CHILDREN & 2.00 & 1.89 & 2.00 & 2.00 \\
\hline MARRIED & 0.56 & & 0.59 & \\
\hline \multicolumn{5}{|l|}{ EDUCATION (the highest attained level) } \\
\hline ELEMENTARY SCHOOL & 0.07 & 0.13 & 0.19 & 0.19 \\
\hline HIGH-SCHOOL DEGREE & 0.57 & 0.55 & 0.51 & 0.56 \\
\hline BACHELOR'S DEGREE & 0.20 & 0.16 & 0.26 & 0.16 \\
\hline MASTER'S DEGREE (or higher) & 0.16 & 0.16 & 0.04 & 0.09 \\
\hline HOURS OF WORK*) & 1378.1 & 1921.9 & 1381.0 & 1804.8 \\
\hline SHARE WITH FULL-TIME WORK*) & 0.81 & 0.92 & 0.96 & n.a. \\
\hline HOURLY WAGE RATE $(\boldsymbol{(}) *)$ & 10.8 & 13.1 & 17.0 & 21.5 \\
\hline LABOUR INCOME $(€ 10000) *)$ & 1.35 & 2.16 & 2.29 & 3.27 \\
\hline YEARS OF WORK EXPERIENCE & 8.2 & 13.1 & 8.1 & 11.7 \\
\hline FAMILY INCOME (€ 10000$)$ & 3.46 & & 4.06 & \\
\hline \multicolumn{5}{|l|}{ SECTOR OF EMPLOYMENT } \\
\hline STATE & 0.09 & 0.12 & 0.05 & 0.07 \\
\hline MUNICIPALITY & 0.43 & 0.12 & 0.42 & 0.07 \\
\hline PRIVATE & 0.42 & 0.68 & 0.51 & 0.84 \\
\hline OTHER & 0.06 & 0.08 & 0.02 & 0.02 \\
\hline LIVING IN A BIG CITY **) & 0.39 & 0.39 & 0.12 & 0.12 \\
\hline \multicolumn{5}{|l|}{ PARENTAL LEAVE } \\
\hline TAKE-UP OF LEAVE (weeks) & 42.5 & 3.8 & 31.4 & 1.27 \\
\hline SHARE OF THE FATHERS HAVING & & 69.0 & & 58.8 \\
\hline \multicolumn{5}{|l|}{ LEAVE } \\
\hline CHILDCARE FEE $(\boldsymbol{€})$ & 230.0 & & 206.8 & \\
\hline COMPENSATION RATE 1 ***) & 0.84 & 0.79 & 0.80 & 0.53 \\
\hline COMPENSATION RATE2 & 0.81 & 0.76 & 0.48 & 0.35 \\
\hline COMPENSATION RATE3 & 0.17 & 0.17 & & \\
\hline NUMBER OF OBSERVATIONS & 9756 & 9756 & 3172 & 3048 \\
\hline
\end{tabular}

Notes: See Table A1 
Table A3. Descriptive statistics of the sample of parents, the Swedish (1993-1998) and the Danish (19931996), where the mother gives birth to her third or higher order child. All variables related to the market work are records from a year prior to the birth. Monetary values are given in Euros in 2000 prices.

\begin{tabular}{|c|c|c|c|c|}
\hline \multirow[t]{2}{*}{ VARIABLE } & \multicolumn{2}{|l|}{ SWEDEN } & \multicolumn{2}{|l|}{ DENMARK } \\
\hline & MOTHERS & FATHERS & MOTHERS & FATHERS \\
\hline AGE & 33.2 & 35.9 & 33.2 & 35.3 \\
\hline AGE WHEN HAVING THE FIRST CHILD & 25.4 & 27.6 & 24.3 & n.a. \\
\hline HAVING CHILDREN 0-2 YEARS OF AGE & 0.14 & 0.13 & 0.38 & 0.39 \\
\hline HAVING CHILDREN 3-6 YEARS OF AGE & 0.66 & 0.80 & 0.71 & 0.72 \\
\hline NUMBER OF CHILDREN & 3.37 & 3.17 & 3.20 & 3.18 \\
\hline MARRIED & 0.75 & & 0.70 & \\
\hline \multicolumn{5}{|l|}{ EDUCATION (the highest attained level) } \\
\hline ELEMENTARY SCHOOL & 0.14 & 0.20 & 0.26 & 0.23 \\
\hline HIGH-SCHOOL DEGREE & 0.55 & 0.52 & 0.39 & 0.51 \\
\hline BACHELOR'S DEGREE & 0.18 & 0.13 & 0.31 & 0.17 \\
\hline MASTER'S DEGREE (or higher) & 0.14 & 0.15 & 0.04 & 0.09 \\
\hline HOURS OF WORK*) & 1386.2 & 1958.0 & 1329.4 & 1741.1 \\
\hline SHARE WITH FULL-TIME WORK*) & 0.77 & 0.92 & 0.93 & n.a. \\
\hline HOURLY WAGE RATE $(\boldsymbol{(}) *)$ & 10.8 & 13.3 & 17.0 & 21.1 \\
\hline LABOUR INCOME (€ 10000$) *)$ & 1.29 & 2.12 & 2.19 & 3.21 \\
\hline YEARS OF WORK EXPERIENCE & 9.2 & 15.7 & 9.0 & 12.9 \\
\hline FAMILY INCOME (€ 10 000) & 3.83 & & 4.16 & \\
\hline \multicolumn{5}{|l|}{ SECTOR OF EMPLOYMENT } \\
\hline STATE & 0.07 & 0.12 & 0.05 & 0.06 \\
\hline MUNICIPALITY & 0.53 & 0.15 & 0.52 & 0.10 \\
\hline PRIVATE & 0.32 & 0.63 & 0.38 & 0.83 \\
\hline OTHER & 0.08 & 0.10 & 0.05 & 0.01 \\
\hline LIVING IN A BIG CITY **) & 0.34 & 0.34 & 0.09 & 0.09 \\
\hline \multicolumn{5}{|l|}{ PARENTAL LEAVE } \\
\hline TAKE-UP OF LEAVE (weeks) & 43.1 & 4.0 & 32.5 & 1.2 \\
\hline SHARE OF THE FATHERS HAVING & & 72.5 & & 58.2 \\
\hline \multicolumn{5}{|l|}{ LEAVE } \\
\hline CHILDCARE FEE $(\boldsymbol{€})$ & 229.0 & & 205.2 & \\
\hline COMPENSATION RATE 1 ***) & 0.84 & 0.79 & 0.85 & 0.54 \\
\hline COMPENSATION RATE2 & 0.81 & 0.76 & 0.49 & 0.34 \\
\hline COMPENSATION RATE3 & 0.17 & 0.17 & & \\
\hline NUMBER OF OBSERVATIONS & 7517 & 7517 & 1270 & 1197 \\
\hline
\end{tabular}

Notes: See Table A1 
Table A4. The results from the estimations of the proportional hazard model of re-entering the labour market after childbirth according to birth order.

\begin{tabular}{|c|c|c|c|c|c|c|}
\hline \multirow[t]{2}{*}{ VARIABLE } & \multicolumn{2}{|c|}{$\begin{array}{l}\text { PARAMETER ESTIMATE } \\
\text { (STANDARD ERROR) }\end{array}$} & \multicolumn{2}{|c|}{$\begin{array}{l}\text { PARAMETER ESTIMATE } \\
\text { (STANDARD ERROR) }\end{array}$} & \multicolumn{2}{|c|}{$\begin{array}{l}\text { PARAMETER ESTIMATE } \\
\text { (STANDARD ERROR) }\end{array}$} \\
\hline & Denmark & Sweden & Denmark & Sweden & Denmark & Sweden \\
\hline \multicolumn{7}{|l|}{ Family policy regimes: } \\
\hline Compensation rate & $\begin{aligned}- & 0.595 * * * \\
& (0.121)\end{aligned}$ & $\begin{aligned}- & 0.638 * * * \\
& (0.197)\end{aligned}$ & $\begin{array}{c}-0.599 * * * \\
(0.139)\end{array}$ & $\begin{array}{c}-0.235 * \\
(0.103)\end{array}$ & $\begin{array}{r}-0.071 \\
(0.213)\end{array}$ & $\begin{array}{c}-0.343 * * \\
(0.113)\end{array}$ \\
\hline Father's leave & $\begin{array}{c}0.053 * * * \\
(0.009)\end{array}$ & $\begin{array}{c}0.036 * * \\
(0.013)\end{array}$ & $\begin{array}{c}0.062 * * * \\
(0.013)\end{array}$ & $\begin{array}{c}0.040 * * * \\
(0.007)\end{array}$ & $\begin{array}{l}0.026 \\
(0.017)\end{array}$ & $\begin{array}{c}0.045^{* * *} \\
(0.008)\end{array}$ \\
\hline Childcare price & $\begin{array}{c}0.032 \\
(0.103)\end{array}$ & $\begin{array}{c}0.024 \\
(0.087)\end{array}$ & $\begin{array}{l}-0.031 \\
(0.104)\end{array}$ & $\begin{array}{c}-0.113 * * \\
(0.043)\end{array}$ & $\begin{array}{r}-0.183 \\
(0.182)\end{array}$ & $\begin{array}{l}-0.076 \\
(0.049)\end{array}$ \\
\hline Big city & $\begin{array}{r}-0.258 \\
(1.591)\end{array}$ & $\begin{array}{l}-0.512 \\
(0.873)\end{array}$ & $\begin{array}{l}-1.282 \\
(2.063)\end{array}$ & $\begin{array}{c}-2.578 * * * \\
(0.490)\end{array}$ & $\begin{array}{r}-0.483 \\
(4.786)\end{array}$ & $\begin{aligned}- & 1.650 * * \\
& (0.565)\end{aligned}$ \\
\hline Childcare price $*$ city & $\begin{array}{c}0.145 \\
(0.734)\end{array}$ & $\begin{array}{l}0.150 \\
(0.367)\end{array}$ & $\begin{array}{l}0.597 \\
(0.951)\end{array}$ & $\begin{array}{c}1.053 * * * \\
(0.206)\end{array}$ & $\begin{array}{c}0.188 \\
(2.227)\end{array}$ & $\begin{array}{c}0.688 * * \\
(0.237)\end{array}$ \\
\hline \multicolumn{7}{|l|}{ Labour market status } \\
\hline Sector of occ.: state & $\begin{array}{c}0.233 * * \\
(0.086)\end{array}$ & $\begin{array}{c}0.198 * * \\
(0.072)\end{array}$ & $\begin{array}{c}0.129 \\
(0.097)\end{array}$ & $\begin{array}{c}0.192 * * * \\
(0.039)\end{array}$ & $\begin{array}{c}0.260 \\
(0.164)\end{array}$ & $\begin{array}{c}0.352 * * * \\
(0.052)\end{array}$ \\
\hline Sector of occ.: municip. & $\begin{array}{c}0.066 \\
(0.049)\end{array}$ & $\begin{array}{l}0.102 * \\
(0.050)\end{array}$ & $\begin{array}{c}-0.058 \\
(0.052)\end{array}$ & $\begin{array}{c}0.045 \\
(0.025)\end{array}$ & $\begin{array}{r}-0.040 \\
(0.084)\end{array}$ & $\begin{array}{c}0.116 * * * \\
(0.029)\end{array}$ \\
\hline Unemp. prior to birth & $\begin{array}{c}0.261 * * * \\
(0.051)\end{array}$ & $\begin{array}{c}-0.371 * * * \\
(0.113)\end{array}$ & $\begin{array}{c}0.208 * * * \\
(0.060)\end{array}$ & $\begin{aligned}-0.182 * * * \\
(0.042)\end{aligned}$ & $\begin{array}{l}0.242 * \\
(0.098)\end{array}$ & $\begin{array}{c}-0.208 * * * \\
(0.049)\end{array}$ \\
\hline \multicolumn{7}{|l|}{ Human capital variables: } \\
\hline Age & $\begin{array}{r}-0.007 \\
(0.008)\end{array}$ & $\begin{array}{r}-0.010 \\
(0.010)\end{array}$ & $\begin{array}{c}0.006 \\
(0.009)\end{array}$ & $\begin{array}{l}-0.010 \\
(0.005)\end{array}$ & $\begin{array}{r}-0.012 \\
(0.012)\end{array}$ & $\begin{array}{c}-0.029 * * * \\
(0.005)\end{array}$ \\
\hline Educ: High school & $\begin{array}{c}0.266 * * * \\
(0.054)\end{array}$ & $\begin{array}{l}0.169 \\
(0.114)\end{array}$ & $\begin{array}{c}0.105 \\
(0.056)\end{array}$ & $\begin{array}{c}0.133 * * \\
(0.047)\end{array}$ & $\begin{array}{c}0.008 \\
(0.086)\end{array}$ & $\begin{array}{c}0.168 * * * \\
(0.042)\end{array}$ \\
\hline Educ: Short university & $\begin{array}{c}0.369 * * * \\
(0.067)\end{array}$ & $\begin{array}{c}0.410 * * * \\
(0.121)\end{array}$ & $\begin{array}{c}0.199 * * \\
(0.067)\end{array}$ & $\begin{array}{c}0.334 * * * \\
(0.053)\end{array}$ & $\begin{array}{c}0.262 * * \\
(0.098)\end{array}$ & $\begin{array}{c}0.442 * * * \\
(0.051)\end{array}$ \\
\hline Educ: Long university & $\begin{array}{c}0.634 * * * \\
(0.112)\end{array}$ & $\begin{array}{c}0.701 * * * \\
(0.126)\end{array}$ & $\begin{array}{c}0.390 * * \\
(0.120)\end{array}$ & $\begin{array}{c}0.570 * * * \\
(0.059)\end{array}$ & $\begin{array}{c}0.231 \\
(0.185)\end{array}$ & $\begin{array}{c}0.651 \text { *** } \\
(0.055)\end{array}$ \\
\hline Years of work exp. & $\begin{array}{c}0.072 * * * \\
(0.019)\end{array}$ & $\begin{array}{c}0.072 \\
(0.017)\end{array}$ & $\begin{array}{c}0.008 \\
(0.020)\end{array}$ & $\begin{array}{c}0.056 * * * \\
(0.009)\end{array}$ & $\begin{array}{r}-0.018 \\
(0.027)\end{array}$ & $\begin{array}{c}0.063 * * * \\
(0.010)\end{array}$ \\
\hline Yrs. Of work $\exp ^{\wedge} 2 / 100$ & $\begin{array}{c}-0.331^{* *} \\
(0.113)\end{array}$ & $\begin{array}{l}-0.240 \\
(0.095)\end{array}$ & $\begin{array}{r}-0.017 \\
(0.102)\end{array}$ & $\begin{array}{c}-0.159 \text { ** } \\
(0.051)\end{array}$ & $\begin{array}{l}0.317 * \\
(0.130)\end{array}$ & $\begin{array}{c}-0.139 \text { ** } \\
(0.057)\end{array}$ \\
\hline \multicolumn{7}{|l|}{ Family situation: } \\
\hline Marital status: married & $\begin{array}{c}0.050 \\
(0.040)\end{array}$ & $\begin{array}{r}-0.170 \\
(0.102)\end{array}$ & $\begin{array}{c}0.078 \\
(0.042)\end{array}$ & $\begin{array}{r}-0.013 \\
(0.024)\end{array}$ & $\begin{array}{c}0.066 \\
(0.073)\end{array}$ & $\begin{array}{r}-0.028 \\
(0.031)\end{array}$ \\
\hline Family inc $(€ 10000)$ & $\begin{array}{r}-0.004 \\
(0.010)\end{array}$ & $\begin{array}{c}0.004 \\
(0.011)\end{array}$ & $\begin{array}{c}0.015 \\
(0.009)\end{array}$ & $\begin{array}{c}0.001 \\
(0.007)\end{array}$ & $\begin{array}{c}0.004 \\
(0.013)\end{array}$ & $\begin{array}{r}-0.005 \\
(0.004)\end{array}$ \\
\hline Other child: $0-2$ yrs. old & $-\ldots$ & $-\ldots$ & $\begin{array}{l}-0.007 \\
(0.076)\end{array}$ & $\begin{array}{c}0.333 * * * \\
(0.043)\end{array}$ & $\begin{array}{c}0.005 \\
(0.070)\end{array}$ & $\begin{array}{l}0.081 * \\
(0.038)\end{array}$ \\
\hline Other child: 3-6 yrs. old & --- & --- & $\begin{array}{c}0.008 \\
(0.075)\end{array}$ & $\begin{array}{c}0.207 * * * \\
(0.038)\end{array}$ & $\begin{array}{c}-0.058 \\
(0.079)\end{array}$ & $\begin{array}{c}0.013 \\
(0.029)\end{array}$ \\
\hline \multicolumn{7}{|l|}{ Macroeconomic variables: } \\
\hline Unemployment rate & $\begin{array}{c}0.189 \text { *** } \\
(0.015)\end{array}$ & $\begin{array}{c}-0.073 * * \\
(0.027)\end{array}$ & $\begin{array}{c}0.178 * * * \\
(0.015)\end{array}$ & $\begin{array}{c}-0.042 * * \\
(0.014)\end{array}$ & $\begin{array}{c}0.170 * * * \\
(0.024)\end{array}$ & $\begin{array}{c}-0.067 \text { *** } \\
(0.017)\end{array}$ \\
\hline Number of observations & 3675 & 3300 & 3172 & 9756 & 1270 & 7517 \\
\hline
\end{tabular}

Significance levels: $*<0.05, * *<0.01, * * *<0.001$. 